\title{
The Dynamic Interactions Among Trade Openness and Economic Growth: Evidence from Algeria
}

\author{
Dalila TALEB \\ Department of Economics, Faculty of Economic Science, Commercial and Management Sciences, University of Abou Baker Belkaid, \\ Tlemcen, Algeria \\ Email address: \\ talebdalila2005@yahoo.fr \\ To cite this article: \\ Dalila TALEB. The Dynamic Interactions among Trade Openness and Economic Growth: Evidence from Algeria. International Journal of \\ Economic Behavior and Organization. Vol. 5, No. 6, 2017, pp. 162-167. doi: 10.11648/j.ijebo.20170506.16
}

Received: May 3, 2017; Accepted: June 19, 2017; Published: January 8, 2018

\begin{abstract}
The aim of this paper is to try to measure the impact of the trade openness on the economic growth in Algeria using the annual data for the period (1980-2015). In this intent, we considered three openness measures: the ratio of exports to GDP, the ratio of imports to GDP and the ratio of all the exports and the imports to GDP since that, the GDP per capita in real terms is used as an indicator of the economic growth. This analysis is based by the Fully Modified Ordinary Least Squares method said (FMOLS); The empirical results revealed the existence of long-term relationship between the real GDP per capita and Trade liberalization, and show that the trade openness has a significantly positive impact on the economic growth in Algeria, this result highlights that trade openness promote economic growth in Algeria.
\end{abstract}

Keywords: Exports, Imports, Trade Openness, Economic Growth, Gross Domestic Product, Econometric Models, Times Series

\section{Introduction}

The integration of countries into the world economy is often regarded as an important determinant of differences in income and growth across countries. Economic theory has identified the well-known channels through which trade can have an effect on growth. More specifically, trade is believed to promote the efficient allocation of resources, allow a country to realize economies of scale and scope, facilitate the diffusion of knowledge, foster technological progress, and encourage competition both in domestic and international markets that leads to an optimization of the production processes and to the development of new products. [24, 29]

In particular for less-developed countries, trade patterns and changes in those patterns over time are closely associated with the transfer of technology. Also, openness to trade introduces the possibility of an international product cycle, as the production of certain products previously produced by advanced economies migrates to less-developed countries. This process of "product migration" is accompanied by an increase in the trade volumes of less- developed countries and a diffusion of more advanced production technologies, which expands the technology available to less-advanced countries. [8, 9]

The effect of trade policy on income and growth is more controversial. On the one hand, lowering trade barriers is likely to foster international trade by reducing transaction costs, which in turn can enhance economic growth rates. Likewise, it can be argued that developing countries or emerging market economies that are more open to the rest of the world have a greater ability to absorb technologies developed in more advanced nations. On the other hand, it has been argued that some forms of protectionism, e.g., infant industry protection to develop certain industries or sectors or a strategic trade policy in key sectors, can be beneficial for economic development. [30, 42]

\section{Literature Review}

The relationship between international trade and economic growth has received fair attention among the researchers. Among cross country studies, Balassa (1978), Feder (1983), Ram (1985), Ahmad (1991), McNab and Moore (1998) and Awokuse (2007) support a positive association between export growth and output growth in developing countries. However these studies did not validate the direction of 
causality between export and economic growth but inherently assumed positive causal effect of export on output growth. Additionally these studies suffered from classical omittedvariables problem where effects of country specific factors were ignored. Ram (1987), Salvatore and Hatcher (1991) examined the export-led economic growth hypothesis using ordinary least square method and argued that exports are likely to contribute positively towards foreign exchange reserves and thereby facilitate import of better technologies and production methods. Subsequent studies on individual countries like Hsiao (1987), Dodaro (1993), Sharma and Dhakal (1994), and Riezman et al. (1996) suggest that export growth has no causal effect on output growth in the majority of developing countries. However, most of these studies employed causality using VAR and thus prohibits the possibility of a long-run or cointegrating relationship between the level of exports and the level of output a priori. Granger (1988) and Toda and Phillips (1993) highlighted the methodological limitations of causality based on VAR as employed in these studies. Among other studies, Van den Berg and Schmidt (1994), Ahmad and Harnhirun (1995), Dutt and Ghosh (1996), Love and Chandra (2004), BahmaniOskooee (1991) suggest that in most developing countries there is a positive long run relationship between exports and output, and that causality is running from exports to output or in both directions. However, Moosa (1999) failed to detect long run and short run relationship between export and growth using cointegration and causality tests for Australia. Ekanayake (1999) provides a good summary of literature on the issue. However, most of these studies are based on individual country time-series data and may have been impaired by a short data span that lowers the power of the unit root and cointegration test. Contemporary research on the issue focuses more on panel data analysis to test causality and cointegration especially for research on a group of countries. On his work on cross country growth, Islam (1995) argued that panel procedures may provide evidences significantly different than individual cross country studies.

Yao (2006) adopted panel unit root test and dynamic panel data estimating technique to suggest that both exports and FDI have a strong and positive effect on economic growth. The result indicates that two development policies adopted in China are useful for other developing and transitional economies: export promotion and adoption of world technology and business practices. Parida and Shahoo (2007) examined export led growth hypothesis for four developing countries of South Asia like India, Pakistan, Bangladesh and Sri Lanka using Pedroni's Panel Cointegration Technique.
The study finds long-run equilibrium relationship supporting export- led growth hypothesis. Using panel VECM, Safdari, et al. (2011) observed unidirectional causality running from economic growth to exports for 13 developing countries. Zeren and Savrul (2013) examined the export led growth hypothesis in 15 selected European countries using panel cointegration and concluded existence of a long term relationship between economic growth and exports. However, Utahan (2015) and Bhattacharya (2016) find less support for positive linkage between trade openness and economic growth using panel approach.

The motivation of the study stems from diverse findings on the issue. The interrelated relationship between export of goods and services, import of goods and services and economic growth has always been considered as an important topic for discussion; however the empirical work on the relationship among these three variables is limited so far as Algeria is concerned [10].

\section{Data and Methods}

Annual data of export of goods and services and import of goods and services and Gross Domestic Product (GDP) per capita (constant 2005 US\$) have been taken from the World Bank. The time period of the study is 1980 to 2015 .

To model the effect of openness on economic growth we follow the standard literature in specifying a Solow Growth function pertaining to the economic model below:

$$
\mathrm{GDPPC}=\mathrm{f}(\mathrm{OPEN}, \mathrm{X})
$$

RGDPPC denotes real gross domestic product per capita, OPEN denotes measures of openness (we adopt three measures of openness, see below), $\mathrm{X}$ denotes a set of control variables which can affect economic growth. These variables are, CS (capital stock as a percentage of GDP), and HUMAN (a proxy of human capital namely labor force as a percentage of GDP). We therefore assumed that economic growth can approximated by the following production function:

$$
\mathrm{GDPPC}=\mathrm{f}(\mathrm{OPEN}, \mathrm{CS}, \mathrm{HUMAN})
$$

We specified three regressions to analyze the relationship between openness and economic growth. The regressions differ in terms of the measure of openness.

OP 1: Imports plus Exports as a percentage of GDP

OP 2: Imports as a percentage of GDP

OP 3: Exports as a percentage of GDPThe three regressions in log forms are as follows:

$$
\begin{gathered}
\log G d p p c_{t}=\alpha_{0}+\alpha_{1} \log O p_{1 t}+\alpha_{2} \log C_{t}+\alpha_{3} \log L f_{t}+\xi_{t 1} \\
\log G d p p c_{t}=\lambda_{0}+\lambda_{1} \log O p_{2 t}+\lambda_{2} \log C s_{t}+\xi_{t 2} \\
\log G d p p c_{t}=\delta_{0}+\delta_{1} \log O p_{3 t}+\delta_{2} \log C s_{t}+\delta_{3} \log L f_{t}+\boldsymbol{\xi}_{t 3}
\end{gathered}
$$

Firstly, we present the econometric methodology adopted to achieve the objective of this paper and secondly, the empirical results.
The empirical results commences by testing the order of integration of the variables. The Augmented Dickey Fuller approach was employed. 


\section{Results and Discussions}

\subsection{The Stationary of the Time Series}

Each time series was examined to determine if it is stationary or non - stationary employing the unit roots test. If a time series is found to be non-stationary, subsequently the examination was undertaken to determine if its first difference is stationary $[11,13]$. Using this procedure, the order of integration of a time series is determined. Table (1) presents the results of Augmented Dickey-Fuller (ADF) test statistics for the log levels and the first differences of the logs of the annual time series data [15].

From table 1 it is evident that all time series are compatible with the hypothesis that stationarity characterizes the variables in this study. Since (the ADF absolute computed values, are greater than the absolute critical values, at the first difference for variables, where all the statistics are significant.

Table 1. Unit Root Test (Augmented Dickey Fuller).

\begin{tabular}{llll}
\hline \multirow{2}{*}{ Variable } & ADF & \\
\cline { 2 - 3 } & Level Form & First difference & I $(1)$ \\
\hline Log Gdppc & $-0.48801(0.8806)$ & $*-2.956378(0.0504)$ & I (1) \\
Log Op $_{1}$ & $-1.42737(0.5566)$ & $-5.281709(0.0001)$ & I $(1)$ \\
Log Op $_{2}$ & $-2.830337(0.0653)$ & $-5.761745(0.0000)$ & I $(1)$ \\
$\operatorname{Log~Op}_{3}$ & $-1.8569(0.3477)$ & $-5.256316(0.0002)$ & I $(1)$ \\
Log Cs & $-1.016276(0.7349)$ & $-3.2230 *(0.0281)$ & I (1) \\
Log Lf & $0.5984(0.9875)$ & $-5.8693(0.0000)$ & \\
\hline
\end{tabular}

Source: prepared by the researcher, depending on the program eviews 8

\subsection{Test of Stationarity of Residue}

Including that time series is stable at the difference I, in order to estimate the function using fully modified last square must study the stability of the residue at the level by the test (ADF) of functions. After its appreciation in ordinary least squares (OLS) results came as follows in table 2:

According to the results obtained by the time series three function is stationary at $5 \%$ (in absolute value) this means that there is a co-integration between the variables and there is a long-term relationship, and thus can estimate the function using fully modified last square FMOLS.
Table 2. Test of Stationarity of Residue.

\begin{tabular}{llll}
\hline$\varepsilon_{t 1}$ & $\varepsilon_{t 2}$ & $\varepsilon_{t 3}$ & Variables \\
\hline$-3.702155^{* * *}$ & $-3.761870 * * *$ & $-3.819981 * * *$ & Level \\
-0.0089 & -0.0076 & -0.0066 & \\
\hline
\end{tabular}

Probabilities of rejection of null hypothesis are presented in parenthesis. ***, $* *$ and $*$ denotes significance at $\mathrm{p}<1 \%, 5 \%$ and $10 \%$.

\subsection{The Optimal Lag Length Selection}

The next step is to formulate and estimate the FMOLS model. The initial task in estimating the FMOLS model is to determine the optimum order of lag length. This is important since under parametrization would tend to bias the results and over-parametrization would diminish the power of tests. The optimal lag length of the lagged differences of the tested variable is determined by minimizing the Akaike

Information Criteria (AIC) and Schwarz Bastian Criteria (SBIC). Table 3 shows the selected lag length by criteria, all the criteria (LR, FPF, AIC, SC and HQ) recommended a joint lag 1.

Table 3. The Optimal Lag Length.

\begin{tabular}{llllll}
\hline Lag & LR & FPE & AIC & SC & HQ \\
\hline 0 & - & 8.89 e+12 & 44.00476 & 44.23829 & 44.07947 \\
1 & $315.7767 *$ & 93363096 & 32.51407 & $33.91526 *$ & $32.96232 *$ \\
2 & 34.98314 & $91251404 *$ & 32.33952 & 34.90838 & 33.16132 \\
3 & 23.98713 & 1.35 e+08 & $32.29282 *$ & 36.02934 & 33.48816 \\
\hline \multicolumn{7}{r}{ indicates lag order selected by the criterion }
\end{tabular}

\subsection{Fully Modified OLS (FMOLS) Analysis}

Having established that there is a linear combination that keeps the variables in proportion to one another in the long run, we can proceed to generate individual long run estimates for our regression).

The FMOLS estimator not only generates consistent estimates of the parameters in small samples but is control for endogeneity of the regressors and serial correlation. Further, it addresses the problem of simultaneity biases [6,7], table 4 below present's estimates of the cointegration vectors and p-value for models (1), (2) and (3).

Table 4. FMOLS Estimates.

\begin{tabular}{|c|c|c|c|c|c|c|}
\hline & \multicolumn{2}{|l|}{ Model 1} & \multicolumn{2}{|l|}{ Model 2} & \multicolumn{2}{|l|}{ Model 3} \\
\hline & coefficient & p-value & coefficient & p-value & coefficient & p-value \\
\hline $\log O p_{1}$ & 1.86829 & 0.0555 & - & & - & \\
\hline $\log \mathrm{Op}_{2}$ & - & & 0.897345 & 0.0486 & - & \\
\hline $\log \mathrm{Op}_{3}$ & - & & - & & 2.905590 & 0.0002 \\
\hline $\log \mathrm{Cs}$ & -0.8818 & 0.0000 & -1.016125 & 0.0600 & -0.90364 & 0.0000 \\
\hline $\log \operatorname{Lf}$ & 0.312344 & 0.0000 & 0.283975 & 0.0000 & 0.321856 & 0.0000 \\
\hline
\end{tabular}

Source: prepared by the researcher, depending on the program eviews 8

Interpretation of the FMOLS model shows that one variable Log Cs is not significant whereas the other variables are significant at $1 \%$. Openness has the expected sign and is significant.

The $\mathrm{R}^{2}$ of $91 \%$ reflects the standing of independent variables in explaining long-run real GDP per capita in Algeria.

The empirical estimates confirm the positive effect of the opening on the growth (positive and significant effect in the three models). However, the identification of the effect of 
human capital is far from being obvious (positive and significant effect

This shows that the opening of developing countries has, without ambiguity, a positive and significant effect on their economic growth on the one hand, and that on the other hand, such an effect passes through the following channels:

First, exports allow developing countries to obtain foreign currency to finance imports and the debt of a rating and encourage exporting enterprises to be competitive, using a better technology, to be able to make a place in the world market. This technology can, moreover, is broadcast to the non-exporters and thus improve their productivity. however, that most of the national exports are hydrocarbons and raw materials, they play an important role in determining the output levels and national income and the current reality for export in Algeria of various goods and services outside the hydrocarbons sector very modest.

Secondly, the developing countries have a negligible level in R\&D. The opening allows them to access to knowledge and knowledge affairs more particularly through the importation of foreign goods necessary in the process of their production such that the property of equipment and property intermediaries.

Third, the installation of the firms multinationals in developing countries is favorable in the measure or it increases competition and encourages domestic firms to improve their technologies and reamenager their methods of management and organization of a part. On the other hand, it allows you to transfer the foreign technology to these countries and to stimulate domestic firms. Furthermore, the firms involved multinationals has the decrease of unemployment in the developing countries by hiring skilled workers and non-qualified.

However, the human capital in the developing countries does not allow them to take advantage of the opening. This may be the result of the policy of austerity pursued by these developing countries to repay the debt. They must make efforts to improve both quantitatively and qualitatively this factor to be able to assimilate the foreign technology and the transfer to the whole of the economy.

Finally, we have found that the capital stock has a negative impact on growth and the reason for this is that the faltering investment plans at the macroeconomic level at the implementation stage, due to a poor coordination between the fiscal policies of the state and investment policy.

\section{Conclusion}

This paper investigates the relationship between openness, and economic growth in Algeria. As argued by many studies, our findings showed that openness is significance in explaining economic growth and supported, Through this study, we found that:

Trade openness positively affect the growth of the Algerian economy, and by increasing exports, which in turn contributes to the increase of foreign direct investment value through competition between domestic and foreign investment and thus opening up more to the outside world.

From a policy perspective, the results suggest that, Algerian policy makers should focus on financial development and financial sector reforms to sustain steady economic growth in the country, regardless revenue of the hydrocarbons sector. A well-functioning financial institution can drive the economy to her desired height. Also, there is a dire need for the diversification of the economy to reduce over dependency on the hydrocarbon sector to guard against external shocks in terms of falling oil and gas price. Furthermore, future studies are required to apply better proxies to achieve better results.

\section{References}

[1] Ahmad, J.; Kwan, A. C. C. (1991), Causality between exports and economic growth: Empirical evidence from Africa, Economics Letters, Vol. 37, No. 3, pp. 243-248.

[2] Ahmad J, Harnhirun S. (1995). Unit Roots and Cointegration in Estimating Causality between Exports and Economic Growth: Empirical Evidence from the ASEAN Countries. Economics Letters. 49, 329-334.

[3] Awokuse, T. O. (2007), Causality between exports, imports, and economic growth: Evidence from transition economies, Economics Letters, Vol. 94, No. 3, pp. 389-395.

[4] Balassa B. (1978). Exports and Economic Growth: Further Evidence. Journal of Development Economics. 5:2, 181-189.

[5] Bahmani-Oskooee, M.; Mohtadi, H.; Shabsigh, G. (1991), Exports, growth and causality in LDCs: A re-examination, Journal of Development Economics, Vol. 36, No.2, pp. 405415.

[6] Banerjee, A.; Dolado, J. J.; Galbraith, J.; Hendry, D. F. (1993), Co-integration, Error Correction, and the Econometric Analysis of Non-Stationary Data, Oxford University Press, Oxford.

[7] Banerjee, A.; Dolado, J. J.; Mestre, R. (1998), Errorcorrection Mechanism Tests for Cointegration in a Singleequation Framework, Journal of Time Series Analysis, Vol. 19, No. 3, pp. 267 - 283.

[8] Barro, R. J.; Lee, J. W. (1994), Sources of economic growth, Carnegie-Rochester Conference Series on Public Policy, Vol. 40, pp. 1-46.

[9] Barro, R. J.; Sala-i-Martin, X. (1995), Economic Growth, McGraw-Hill, Cambridge, MA. Brazilian Journal of Business and Economics, Vol 3. No. 2, pp. 14-21.

[10] Bhattacharya. M, Bhattacharya S. N.(2016). International Trade and Economic Growth: Evidences From The Brics. Journal of Applied Economics and Business Research JAEBR, 6 (2): 150-160.

[11] Breitung, J. (2000), The local power of some unit root tests for panel data. Advances in Econometrics, Vol. 15: Nonstationary Panels, Panel Cointegration, and Dynamic Panels, ed. B. H. Baltagi, pp.161--178.

[12] Chang, R.; Kaltani, L.; Loayza, N. (2009), Openness is Good for Growth: The Role of Policy Complementarities, Journal of Development Economics, Vol. 90, pp. 33-49. 
[13] Choi, I. (2001), Unit root tests for panel data, Journal of International Money and Finance, Vol. 20, No. 2, pp. 249-272.

[14] Chow, P. (1987), Causality between exports growth and industrial development. Journal of Development Economics, Vol. 26, pp. 55--63.

[15] Dickey, D. A.; Fuller, W. A. (1979), Distribution of the Estimators for Autoregressive Time Series With a Unit Root, Journal of the American Statistical Association, Vol. 74, No. 366, pp. 427-431.

[16] Dodaro S. (1993). Exports and Growth: A Reconsideration of Causality. Journal of Developing Areas. 27, 227-244

[17] Dollar, D. (1992), Outward-oriented Developing Economies Really Do Grow More Rapidly: Evidence from 95 LDCs, 1976-85, Economic Development and Cultural Change, Vol. 40, No. 3, pp. 523-44.

[18] Dollar, D.; Kraay, A. (2002), Growth is good for the poor. Journal of Economic Growth, Vol. 7, No. 3, pp. 195-- 225.

[19] Dutt SD, Ghosh D. (1996). The Export Growth-Economic Growth Nexus: A Causality Analysis. The Journal of Developing Areas, 30:2, 167-182.

[20] Easterly, W.; Levine, R. (2001), What have we learned from a decade of empirical research on growth? It's Not Factor Accumulation: Stylized Facts and Growth Models, World Bank Economic Review, Vol. 15, No. 2, pp 177-219.

[21] Ekayanake EM. (1999). Exports and Economic Growth in Developing Countries: Cointegration and Error-Correction Models. Journal of Economic Development. 24:2, 43-56.

[22] Edwards, S. (1998), Openness, Productivity, and Growth: What Do We Really Know?, Economic Journal, Vol.108 (447), pp. 383-98.

[23] Feder, G. (1982). On Exports and Economic Growth. Journal of Development Economics, 12, 59-73.

[24] Grossman, G. M.; Helpman, E. (1991), Innovation and Growth in the Global Economy, Cambridge, MA: MIT Press.

[25] Granger CWJ.(1988) Causality, Cointegration, and Control. Journal of Economic Dynamics and Control.12, 551-559.

[26] Halit, Y. (2003), 'Trade Openness and Economic Growth a Cross-Country Empirical Investigation', Journal of Development Economics, Vol. 72, No. 1, October, 57- 89.

[27] Hsiao MCW. (1987) Tests of Causality and Exogeneity between Exports and Economic Growth: The Case of Asian NICs. Journal of Economic Development. 12, 149-159.

[28] Islam N. (1995). Growth Empirics: A Panel Data Approach. Quarterly Journal of Economics. 110, 1127-70.

[29] Krugman, Paul R. (1986). Strategic trade policy and the new international economics. Cambridge, MA.: The MIT Press.

[30] Lee, H. Y., Ricci, L. A. and Rigobon, R. (2004). Once Again, is Openness Good for Growth? Journal of Development Economics, 75, 451-472.

[31] Love J, Chandra R. (2004) Testing Export-led Growth In India, Pakistan and Sri Lanka using a Multivariate Framework. The Manchester School. 72:4, 483-96.

[32] Muhammad, S. (2012), 'Does trade openness affect long run growth? Cointegration, causality and forecast error variance decomposition tests for Pakistan', Economic Modelling, Vol. 29, No. 06, November, 2325-2339.

[33] McNab R, Moore R. (1998). Trade Policy, Export Expansion, Human Capital and Growth. Journal of International Trade \& Economic Development. 7:2, 237-256.

[34] Moosa IA. (1999). Is the Export Growth-led Hypothesis valid for Australia? Applied Economics. 31,903-906.

[35] Paridaa PC, Sahoo P. (2007). Export-led growth in South Asia: A Panel Cointegration Analysis. International Economic Journal. 21:2, 155-175.

[36] Pedroni, P. (1999). Critical Values for Cointegration Tests in Heterogeneous Panels with Multiple Regressors. Oxford Bulletin of Economics and Statistics, 61, 653-670.

[37] Pedroni, P. (2000). Fully Modified OLS for Heterogeneous Cointegrated Panels. Advances in Econometrics, 15, 93-130.

[38] Pedroni, P. (2001). Purchasing Power Parity Tests in Cointegrated Panels. The Review of Economics and Statistics, $83,727-731$.

[39] Pedroni, P. (2004). Panel Cointegration: Asymptotic and Finite Sample Properties of Pooled Time Series Tests with an Application to the PPP hypothesis. Econometric Theory, 20, 597-625.

[40] Ram R. (1985) Exports and Economic Growth: Some additional evidence. Economic Development and Cultural Change. 33:2, 415-425.

[41] Ram R. (1987). Exports and Economic Growth in Developing Countries: Evidence from TimeSeries and Cross-Section Data. Economic Development and Cultural Change. 36:1, 51- 72.

[42] Rodriguez, F. and Rodrik, D. (2001). Trade Policy and Economic Growth: A Skeptic's Guide to the Cross-National Evidence". In NBER (ed.), NBER Macroeconomics Annual 2000, NBER Chapters, (Cambridge: National Bureau of Economic Research), 261-338.

[43] Salvatore D, Hatcher T. (1991). Inward Oriented and Outward Oriented Trade Strategies. Journal of Development Studies. $27: 3,7-25$.

[44] Riezman RG, Summers PM, Whiteman CH. (1996) The Engine of Growth or its Handmaiden? A Time Series Assessment of Export-led Growth. Empirical Economics. 21, 77-113.

[45] Rivera-Batiz L, Romer P. (1991) International Trade with Endogenous Technological Change. European Economic Review. 35:4, 971-1004.

[46] Safdari M, Mahmoodi M, Mahmoodi E. (2011) The Causality Relationship between Export and Economic Growth in Asian Developing Countries. American Journal of Scientific Research. 25, 40-45.

[47] Sharma SC, Dhakal D. (1994). Causal Analysis between Exports and Economic Growth in Developing Countries. Applied Economics, 26, 1145-1157.

[48] Ulaşan B. (2015). Trade Openness and Economic Growth: Panel Evidence. Applied Economics Letters. 22:2, 163-167.

[49] Van den Berg H, Schmidt JR. (1994) Foreign Trade and Economic Growth: Time Series Evidence from Latin America. Journal of International Trade and Development. 3, 249-268. 
[50] Yao S.( 2006). On Economic Growth, FDI and Exports in China. Applied Economics. 38:3, 339-351.

[51] Zeren F, Savrul BK. (2013). Revisited Export Led Growth
Hypothesis for selected European Countries: A Panel Hidden Cointegration Approach. Istanbul University Econometrics and Statistics e-Journal. 18:1, 134-151. 